\title{
Productivity of Three Dwarf Kopyor Coconut Varieties from Pati, Central Java, Indonesia
}

\author{
Ismail Maskromo ${ }^{1,2^{*}}$, Hengky Novarianto ${ }^{2}$, Sukendah $^{3}$, Dewi Sukma ${ }^{1}$ and Sudarsono ${ }^{1 *}$
}

\begin{abstract}
Pati Dwarf Kopyor coconut originated from Pati, Central Java is one of the Kopyor coconut populations from Indonesia. Three varieties of Pati Dwarf Kopyor coconut, namely: Kopyor Green Dwarf, Kopyor Brown Dwarf and Kopyor Yellow Dwarf out of six potential varieties have been officially released as local superior varieties by the Minister of Agriculture, Republic of Indonesia at the end of 2010. The objectives of this research were to evaluate the stability of Kopyor fruit production among provenances of Pati Dwarf Kopyor coconuts. Evaluations were conducted especially for the three recently released varieties of Kopyor coconuts. Observations were carried out in 2011 and the collected data were then compared with Kopyor fruit production data collected in 2009 -2010. In three different locations, representatives of 10 Kopyor coconut provenances for each Kopyor variety were observed; therefore, a total of 90 trees were evaluated in this experiment. Observations were conducted for number of total bunches per palm, number of total fruits/per bunch, and the number of harvested Kopyor coconut fruits/per bunch. Three bunches were selected for each of the evaluated provenance. Results of the observation indicated that the observed yield and yield parameters of three Pati Dwarf Kopyor coconut varieties fluctuated by the year of observations. However, in general the observed yield and yield parameters among three varieties were similar. The average number of total bunches observed among three varieties evaluated ranged from 9.6-12.1 bunches per palm; the average number of fruits/per bunch ranged from 5.3-12.4; and the average number of harvested Kopyor fruits/per bunch ranged from 2.0-3.8. The estimated number of total fruits/palm/year among the three varieties ranged from 53.8-128.1 and the percentage of Kopyor fruit production observed among the three varieties evaluated ranged from 24.8-38.9\%. The estimated number of total harvested Kopyor fruits/palm/year ranged from 20.5-39.2, respectively. Rainfall pattern might affect directly or indirectly toward yield and yield components of three Pati Dwarf Kopyor coconut varieties.
\end{abstract}

Keywords: Exotic coconut, Endosperm abnormality, Natural mutation, Fruit yield, Kopyor fruit yield, Rainfall pattern

\footnotetext{
${ }^{1}$ Plant Molecular Breeding Laboratory, Department of Agronomy and Horticulture, Faculty of Agriculture, Jl. Meranti-Darmaga Campus, IPB, Bogor 16680, Indonesia.

${ }^{2}$ Indonesian Palms Research Institute, Jl. Raya Mapanget, P.O. Box 1004, Manado, Indonesia.

${ }^{3}$ Department of Agro-Eco-Technology, Faculty of Agriculture, UPN Veteran, Jawa Timur, Surabaya, Indonesia.

"Contact addresses: is_maskromo@yahoo.com; s_sudarsono@ymail.com
} 


\section{Introduction}

Kopyor Coconut is one of the exotic palms that have a high economic value. The price of Kopyor coconut fruits is relatively more expensive than the regular one. The current price of Kopyor fruit ranged between Rp. $15.000-$ 30.000 , depending on their sizes. However, information about the existence of this unique coconut and its Kopyor fruits production is still limited (Sudarsono et al, 2011).

The Kopyor coconut is hypothesized to have come from natural mutations among coconut provenances (Sudarsono et al, 2012 and Sukendah et al., 2009). According to Santoso (1996), Kopyor is a Javanese term for the matured coconuts having soft and partially detached endosperm from the shell and filling the pit where the coconut water resides. The Makapuno coconut from the Philipines is an other example of coconut mutant exhibiting endosperm abnormality. The Makapuno mutant has also been reported originally occurred among normal coconut populations (Samonthe et al. 1989). Results of biochemical studies on Makapuno fruits indicated the absence of $\alpha-\mathrm{D}$ galactosidase enzyme activity. The absence of this enzyme has been proposed to cause the abnormal endosperm in Makapuno fruit (Mujer et al. 1984). The putative mutant gene in the Macapuno coconut causes the soft endosperm phenotype and the broken association between zygotic embryos and the endosperm tissues (Santos, 1999). Unlike normal coconut fruits, the embryo of Makapuno is unable to germinate naturally.

Kopyor coconut also exhibits endosperm abnormality and came from natural mutation among normal coconut provenances. As a natural mutant, the number of coconut provenances producing Kopyor fruit are supposed to be rare than the normal fruit producing ones. According to Falconer (1985), natural mutation occurs in a relatively very low frequency $\left(10^{-5}-10^{-6}\right.$ each generation). Such probability means that naturally there will be only one mutant among 100,000-1,000,000 progenies. Moreover, the generated mutants most probably are lethal and their survival in nature is limited.

According to those assumptions, Kopyor coconut mutant theoretically should not exist. However, such mutant phenotype is more frequently found in several centres of coconut production in Indonesia. The Kopyor coconut populations were reported exist in Kalianda District, South Lampung (Mahmud, 2000). Result of exploration in East Java by Akuba et al. (2002) successfully identified a number of Kopyor coconut populations in a number of locations. This type of coconut mutant were also existed in Tangerang, Banten (Asmah, 1999), Pati, Central Java, and Ciomas-Bogor, West Java. However, the dwarf type of Kopyor coconut was originally reported in Pati, Central Java (Maskromo, 2005). The Dwarf Kopyor type exists interspersed among the tall type of Kopyor coconut in Pati region.

Recently, three out of six potential varieties of Pati Dwarf Kopyor coconut have been officially released as local superior varieties by Minister of Agriculture, Republic of Indonesia at the end of 2010. These were Pati Kopyor Green Dwarf, Kopyor Brown Dwarf and Kopyor Yellow Dwarf coconut varieties. The objective of this research was to evaluate stability of Kopyor fruit production among provenances of the recently released Pati Dwarf Kopyor coconut varieties.

\section{Materials and methods}

Observations were carried out in 2011 and the collected data were then compared with Kopyor fruit production data collected in 20092010. Kopyor coconut provenances at three (3) locations of Kopyor fruit production centres in Pati were selected and used in this study. The coconut provenances evaluated in the selected locations consisted of a mixture of those producing only normal fruits and those of Kopyor coconut, respectively. However, majority of the coconut provenances in all locations are the Kopyor coconut producing palms.

Surveys were conducted to record existing Kopyor coconut provenances in those locations. 
Representatives of 10 provenances for each Kopyor variety in each location were then selected and used for Kopyor fruit yield evaluation. Selection of Kopyor provenances was based on owner information about the previous Kopyor fruit production by the particular tree.

For each Kopyor provenance, three bunches were selected and the Kopyor fruit yield per bunch was recorded in at least 10 months after pollination. For each bunch, the harvested fruits were grouped into either Kopyor fruits or Normal ones using indigenous knowledge in the region. Identification of Kopyor fruits were done by knocking the husk of the mature nuts. The differences in maturity of Kopyor and Normal nuts facilitated the differentiation among them. According to local farmers, the accuracy of Kopyor fruits identification is close to $100 \%$, especially for coconut fruits at 10 months after pollination.

The observation was conducted by local workers who mastered the indigenous knowledge in Kopyor fruit identification. To validate the data, one or two samples of predicted Kopyor fruit were harvested from every Kopyor provenance and the fruits were opened to determine their identities. Observations were conducted for number of total fruit bunches, total fruits/bunch, Kopyor fruits/bunch, estimated total fruits and Kopyor fruits yield per palm in a year, and Kopyor fruits percentages.

\section{Results and discussions}

Results of the observation for various yield and yield component parameters were presented in Table 1. The average number of total fruit bunches observed among the selected provenances of three Pati Dwarf Kopyor coconut varieties were mostly similar during the three year periods of observation. However, Kopyor Brown Dwarf variety showed higher number of fruit bunches than the Kopyor Yellow Dwarf and Kopyor Green Dwarf one. The average number of fruit bunches observed among three varieties evaluated ranged from 10.2 - 10.7. These number of fruit bunches were lower than the average number of fruit bunches of Kalianda
Tall Kopyor coconut (11.9 -12.6) (Maskromo et $a l, 2012)$. The typical of bunches of the three dwarf varieties of Kopyor coconut are shown in Figure 1.

The average number of fruits/bunch, Kopyor fruits/bunch and percentage of Kopyor fruits harvested among the selected provenances of three Pati Dwarf Kopyor coconut varieties were also mostly similar during the three years periods of evaluation. During the three year periods of observation, the three varieties showed higher number of fruits/bunch and Kopyor fruits/bunch in the year 2009 and 2011 than that in the year 2010 (Table 1). The average number of harvested Kopyor fruits for the three Kopyor coconut varieties ranged from $2.7-3.0$ fruits/bunch (Table 1). The percentage of harvested Kopyor fruits ranged from $35.3 \%$ for Kopyor Green Dwarf, 33.4 \% for Kopyor Brown Dwarf and $35.7 \%$ for Kopyor Yellow Dwarf (Table 1). The number of fruits/bunch and harvested Kopyor fruits/bunch among Pati Dwarf Kopyor coconut were higher than those reported for the Tall Kopyor coconut type observed in Kalianda, South Lampung district, Lampung (Maskromo et al. 2011). Similarly, the average number of Kopyor fruits/bunch and the percentage of Kopyor fruit among Pati Dwarf Kopyor coconut were also higher as compared to those observed in Tall Kopyor coconut type from Kalianda (Maskromo et al. 2011). Kopyor Dwarf coconut types exhibited higher number of Kopyor fruits/bunch than Kopyor Tall coconut because of their differences in pollination pattern (Maskromo and Novarianto, 2007). The dwarf Kopyor type tends to exhibit self pollination while the tall type tend to outcross. The representative segregation of Normal and Kopyor fruits harvested from single bunch was presented in Figure 2.

For the estimated number of total fruit production per palm/year and of total Kopyor fruits/palm/year, the three varieties showed higher numbers in the year of 2009 and 2011 than that in the year of 2010. The estimated number of total fruits/palm/year of Kopyor Green Dwarf is 87.1 fruits, Kopyor Brown Dwarf is 94.3 and Kopyor Yellow Dwarf is 77.3 fruits. The estimated number of total Kopyor 
Table 1. Yield and yield components parameters of three Pati Dwarf Kopyor Coconut varieties during the year 2009 - 2011

\begin{tabular}{|c|c|c|c|c|c|c|c|c|c|c|c|c|}
\hline \multirow{2}{*}{ Parameter } & \multicolumn{3}{|c|}{ KGD } & \multirow{2}{*}{$\begin{array}{l}\text { Aver- } \\
\text { age }\end{array}$} & \multicolumn{3}{|c|}{ KBD } & \multirow{2}{*}{$\begin{array}{c}\text { Aver- } \\
\text { age }\end{array}$} & \multicolumn{3}{|c|}{ KYD } & \multirow{2}{*}{$\begin{array}{l}\text { Aver- } \\
\text { age }\end{array}$} \\
\hline & 2009 & 2010 & 2011 & & 2009 & 2010 & 2011 & & 2009 & 2010 & 2011 & \\
\hline $\begin{array}{l}\text { Number of } \\
\text { bunches/palm }\end{array}$ & 10.3 & 11.0 & 10.2 & 10.5 & 9.8 & 12.1 & 10.3 & 10.7 & 9.6 & 10.3 & 10.8 & 10.2 \\
\hline $\begin{array}{l}\text { Number of } \\
\text { fruits/bunch }\end{array}$ & 10.5 & 6.0 & 8.6 & 8.4 & 9.0 & 5.5 & 12.4 & 9.0 & 9.3 & 5.3 & 8.2 & 7.6 \\
\hline $\begin{array}{l}\text { Number of } \\
\text { Kopyor } \\
\text { fruits/bunch }\end{array}$ & 3.8 & 2.3 & 2.8 & 3.0 & 3.3 & 2.2 & 3.1 & 2.9 & 3.5 & 2.0 & 2.6 & 2.7 \\
\hline $\begin{array}{l}\text { Total number } \\
\text { of fruits/palm }\end{array}$ & 108.4 & 66.0 & 86.9 & 87.1 & 88.2 & 66.6 & 128.1 & 94.3 & 89.6 & 53.8 & 88.5 & 77.3 \\
\hline $\begin{array}{l}\text { Total number } \\
\text { of Kopyor } \\
\text { fruits/palm }\end{array}$ & 39.2 & 24.8 & 27.9 & 30.6 & 32.3 & 25.9 & 31.7 & 30.0 & 33.1 & 20.5 & 28.2 & 27.3 \\
\hline $\begin{array}{l}\text { Percentage of } \\
\text { Kopyor fruits }\end{array}$ & 36.2 & 37.5 & 32.2 & 35.3 & 36.6 & 38.9 & 24.8 & 33.4 & 37.0 & 38.1 & 31.9 & 35.7 \\
\hline
\end{tabular}

Note: - Data of 2009 and 2010 were from "Proposal Pelepasan Tiga Varietas Unggul Lokal Kelapa Genjah Kopyor Pati."

- KGD: Kopyor Green Dwarf, KBD: Kopyor Brown Dwarf, and KYD: Kopyor Yellow Dwarf.
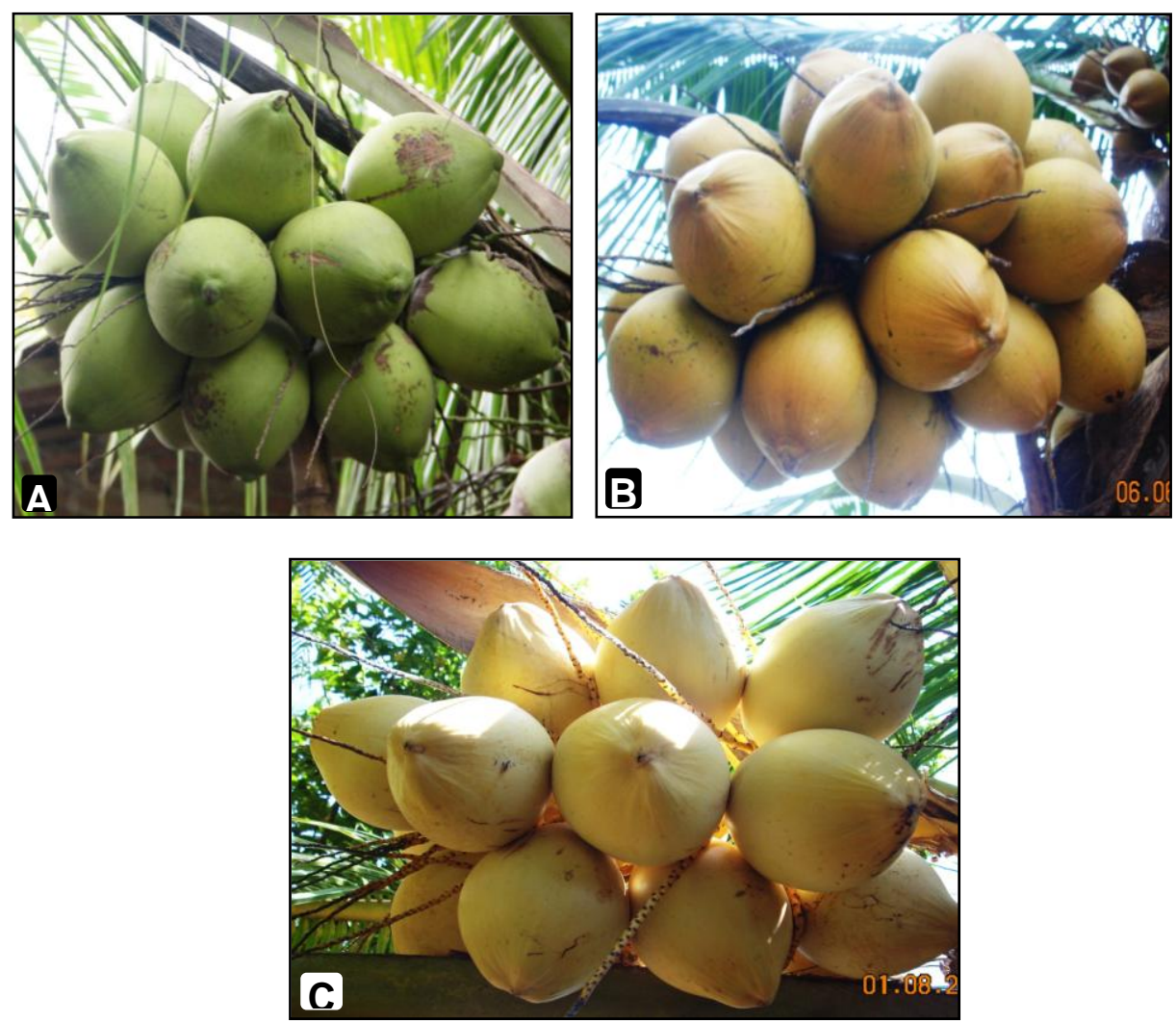

Figure 1. The representative of fruit bunches of the three dwarf Kopyor coconut varieties originated from Pati, Central Java, Indonesia. (A) Kopyor Green Dwarf, (B) Kopyor Brown Dwarf, and (C) Kopyor Yellow Dwarf 
fruits/palm/year among three Pati Kopyor varieties evaluated ranged from 27.3 - 30.6 fruits. The estimated number of total fruits/palm/year and estimated number of total Kopyor fruits/palm/year are also higher than those observed among Kopyor Tall coconut type originated from Kalianda (Maskromo et al. 2011).

In the case of Makapuno, a coconut mutant exhibited abnormal endosperm from the Philippines, there are three different types of Makapuno existed. Attempt to evaluate the existence of such type in Kopyor coconut have been preliminary evaluated in other studies. Results of those observations indicated the presence of nine different Kopyor coconut based on the scores of endosperm quantity in the nuts. According to collected data on the scores of endosperm quantity, Pati Dwarf Kopyor varieties belong to Kopyor with score of endosperm of 16 . The existence of Kopyor coconut with score of endosperm up to 9 are observed only in those originated from Jember and Sumenep, East Java and Kalianda, Lampung, respectively (Maskromo et al. 2012).

Based on those observations, the three Pati Dwarf Kopyor varieties basically showed similar yield potentials. However, there was yield fluctuation by year of observations. Although the number of bunches observed in the year of 2010 was slightly higher than those in the year of 2009 or 2011, the number of fruits/bunch, Kopyor fruits/bunch, estimated fruits/palm/year, and estimated Kopyor fruits/palm/year in the year of 2010 was the lowest.

Rainfall pattern might have had effects on all of the observed yield and yield component parameters. According to Perera et al. (2010), the time required from flower inflorescence initiation up to fruit harvesting was approximately two years. Rainfall pattern might affect the flower inflorescence initiation (Maskromo et al. 2011). Therefore, the negative effects of rainfall pattern toward flower inflorescence initiation in a certain year would affect the next year coconut yield. The existence of adequate rainfall might result in positive effect to the initiation of female flowers and inflorescences of coconuts.

Moreover, rainfall patterns also affect fruit formation. Sayeed (1955) suggested that in addition to genetic factors, the success of pollination and fruit formation in coconut is strongly affected by environmental conditions. Either excessive amount of rainfall or drought stress exposure might cause failure in pollination and in fruit formation. Too many rainy days during pollination period might probably reduce fruit formation because of the pollination process failure.

Therefore, the observed yield fluctuation in the year 2009-2011 may have been due to rainfall pattern in the years before observation. In this evaluation, the total number of fruit bunches and number of fruit per bunch might be affected by a combination of rainfall pattern in one year before observation. The unfavourable effect of drought and heavy rain on fruit set and retention is shown in low yield one year later. Being perennial in nature, coconut palm has a long duration from the initiation of inflorescence primordial to nut maturity (about 44 months) and with longer pre-fertilization period (about 32 months) than post-fertilization (12 months). Hence, the impact of drought occurring at any of the critical stages of coconut inflorescence development affects nut yield (Rajagopal et al 1996; Rajagopal et al. 2000), not only during the drought year but also in following three years making the problem more severe (NareshKumar 2002). The rainfall pattern data for the research locations in Pati, Central Java, during the period of 2006-2010 were presented in Table 2.

Based on those reasoning, rainfall patterns since the year 2007 might determine yield and yield component parameters observed in period of 2009-2011. The rainfall pattern data for Pati region (Table 2) indicated during the year 2007 and early 2008, there was low volume of rainfall (ranged from 853-1077 mm/year) and limited number of rainy days (79-97 days). During the year 2009, volume of rainfall reached $2559 \mathrm{~mm}$ and the number of rainy days was 171 days in this year. The rainfall pattern for 2010 was 
expected similar to that of 2009. Available data for rainfall pattern in 2010 were only up to August 2010.

The number of bunches in the year 2009 was the lowest (Table 3). The number of bunches in 2009 might be affected by low volume of rainfall in 2008. On the other hand, higher volume of rainfall in 2009 up to 2010 should results in more inflorescences in the year 2010 and 2011. These predictions were supported by observation data since there were higher number of fruit bunches in 2010 and 2011 (Table 3).

The average number of fruits/bunch in the year 2010 was the lowest (Table 3). The number of fruits/bunch in 2010 might be affected by both less amount of rainfall and number of rainy days in last year. After pollination and fruit set, it takes time about $10-12$ months for harvesting mature nuts. Both less amount of rainfall and low number of rainy days might affect fruit retention, resulting in a lower number of fruits/bunch. This prediction was supported by observation data since there was less fruits/bunch in 2010 than that either in 2009 or 2011 (Table 3).

The limited amount of rainfall and rainy days might affect negatively toward inflorescence initiation. However, these conditions might be positive for the yield of Kopyor fruits. As it was expected, less rain in 2008 resulted in higher average number of Kopyor fruits/bunch, while more rain in 2009 and 2010 resulted less Kopyor fruits/bunch (Table 3). Although rainfall might have affected Kopyor fruit yield, its effect may not be direct but probably through its negative impacts on fruit retention. Drought conditions because of less rainfal during early coconut fruit development may have contributed to more fruit fall. Moreover, low number of rainy days might actually indicated that the drought period has run most the year, making the fruit fall problem more severe. Such conditions may result in even lower fruit retention and eventually low Kopyor fruit yield.

Formation of Kopyor fruits is mostly genetically controlled. If the hypothesis that the
Kopyor phenotype is controlled by singlerecessive mutant gene $k$ is true, the Kopyor fruits can only be obtained if the genetic constitution of the endosperm is $k k k$. Such condition could only be achieved when the $k$ female gamete is pollinated by $k$ male pollen. Such pollination resulted in formation of $k k$ zygotic embryos and $k k k$ endosperm in the form of Kopyor fruit.

The genetic constitution of Kopyor producing coconut provenances growing in the Pati regions most probably is a heterozygote $K k$. Therefore, probability of generating Kopyor fruits depends on the convergence of the $k$ allele in the female gamete and the $k$ allele carried in the male pollen. Theoretically under the natural conditions, probability of generating Kopyor fruit is approximately $25 \%$ out of total harvested fruits. Results of the observation support this hypothesis, since the Kopyor fruit formation among three Pati Dwarf Kopyor coconut varieties during the three years observation ranged from $24.8-38.9 \%$. The slightly high percentage of Kopyor fruit formation observed during the three years evaluation may be due to the self pollinating nature of the Dwarf Kopyor coconut used or due to a high percentage of immature normal nut falls.

In certain case, the potential yield of Pati Dwarf Kopyor fruit could reach up to $50 \%$ (Maskromo and Novarianto, 2007). Kopyor yield of up to $50 \%$ may be achieved by pollinating the natural Kopyor palm (heterozygote $K k$ ) with pollen of true-to-type Kopyor palm (homozygote $k k$ ). However, Kopyor provenance in the regions are only of natural heterozygote $K k$ palms and there is no homozygote $k k$ one. Therefore, such possibility is inexistence. Moreover, there is a possibility that more than one locus may actually control Kopyor phenotype. If there are two recessive genes and both are independently controlling Kopyor phenotype, in certain case the Kopyor fruit yield may actually reach $50 \%$. However, other mechanisms may also affect Kopyor fruit yield and there will be further investigation about these matters. In the subsequent studies, a number of evaluations will be conducted to elucidate genetic factors affecting yield of Kopyor fruits in coconut. 


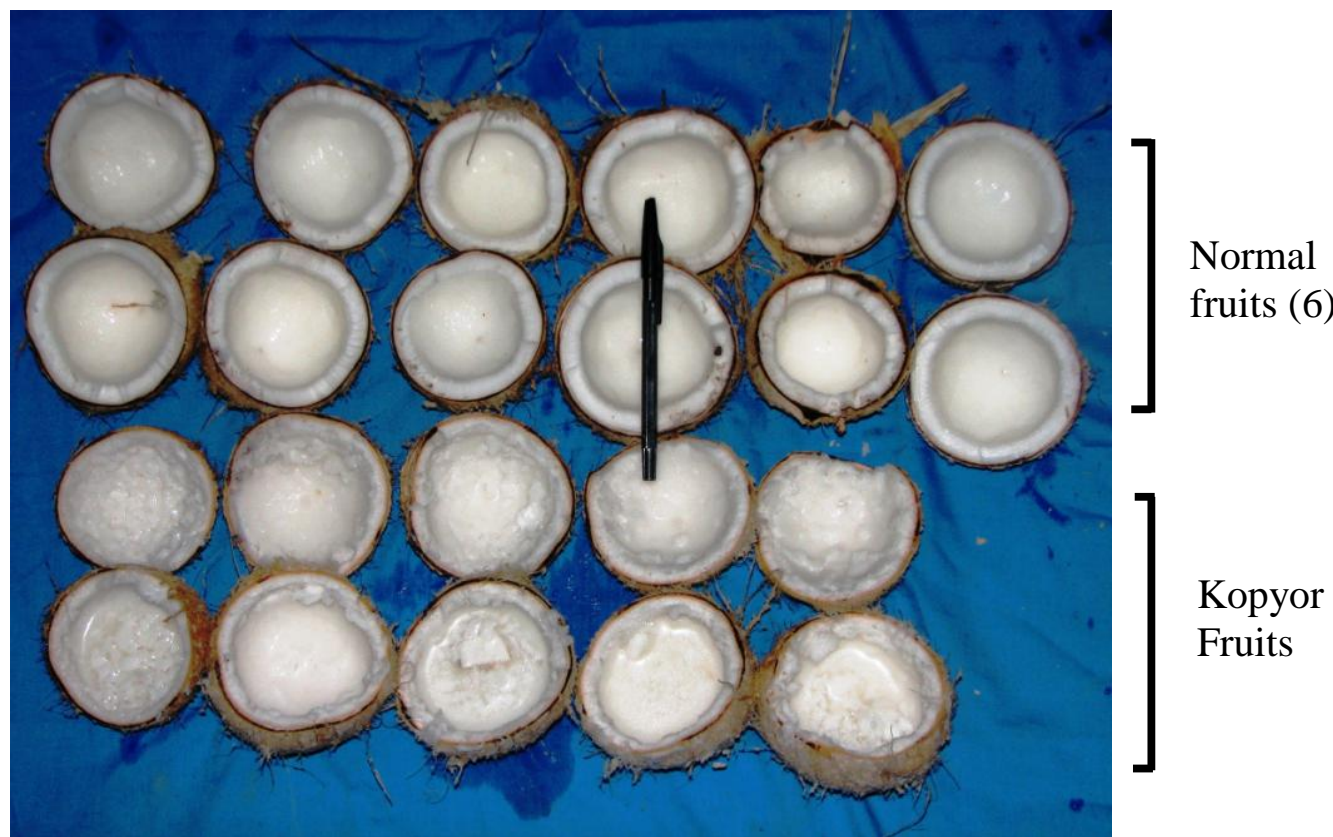

Figure 2. Segregation of normal and Kopyor coconut fruits harvested from a single coconut bunch. The total number of harvested fruit was 11, the normal fruits were 6 (above), and the Kopyor fruits were 5 (below), respectively

Table 2. Monthly and yearly rainfall pattern data during the year of 2008-2010 in the surrounding areas of observation regions, Pati, Central Java, Indonesia

\begin{tabular}{|c|c|c|c|c|c|c|}
\hline \multirow{2}{*}{} & \multicolumn{2}{|c|}{$\mathbf{2 0 0 8}$} & \multicolumn{2}{c|}{2009} & \multicolumn{2}{c|}{2010} \\
\cline { 2 - 7 } & $\begin{array}{c}\text { Volume } \\
\text { (mm) }\end{array}$ & $\begin{array}{c}\text { No. of rainy } \\
\text { day (days) }\end{array}$ & $\begin{array}{c}\text { Volume } \\
\text { (mm) }\end{array}$ & $\begin{array}{c}\text { No. of rainy } \\
\text { day (days) }\end{array}$ & $\begin{array}{c}\text { Volume } \\
\text { (mm) }\end{array}$ & $\begin{array}{c}\text { No. of rainy } \\
\text { day (days) }\end{array}$ \\
\hline Jan & 58 & 9 & 310 & 23 & 600 & 21 \\
Feb & 275 & 16 & 798 & 28 & 143 & 10 \\
Mar & 110 & 13 & 126 & 14 & 187 & 10 \\
Apr & 61 & 10 & 306 & 17 & 192 & 13 \\
May & 67 & 7 & 85 & 13 & 152 & 10 \\
Jun & 54 & 8 & 84 & 9 & 230 & 10 \\
Jul & 18 & 4 & 0 & 0 & 92 & 8 \\
Aug & 0 & 0 & 56 & 9 & 91 & 5 \\
Sep & 56 & 9 & 59 & 6 & NA & NA \\
Oct & 2 & 4 & 86 & 14 & NA & NA \\
Nov & 49 & 4 & 217 & 17 & NA & NA \\
Dec & 103 & 16 & 427 & 21 & NA & NA \\
\hline Total/year & 853 & 100 & 2554 & 171 & $1687 *$ & $87 *$ \\
\hline
\end{tabular}

Source: Local Department of Irrigation, Pati, Central Java. NA: data not available.

*Data up to August 2010. 
Table 3. Possible effects of rainfall pattern on yield and yield component of Pati Dwarf Kopyor coconut from Pati, Central Java, Indonesia

\begin{tabular}{|l|c|c|c|c|}
\hline \multicolumn{1}{|c|}{ Observed Data } & $\mathbf{2 0 0 8}$ & $\mathbf{2 0 0 9}$ & $\mathbf{2 0 1 0}$ & $\mathbf{2 0 1 1}$ \\
\hline Rainfall (mm) $^{1)}$ & 853 & 2,554 & $1,687^{*}$ & NA \\
Rainy day (days) $^{1)}$ & 100 & 171 & $87^{*}$ & NA \\
Average number of bunches $_{\text {Average number of fruits/bunch }}^{2)}$ & NA & 9.9 & 11.1 & 10.4 \\
Average number of Kopyor & NA & 9.6 & 5.6 & 9.7 \\
fruits/inflorescence $^{2)}$ & NA & 3.5 & 2.1 & 2.8 \\
Fruits yield/palm/year $^{3)}$ & NA & 95.4 & 62.1 & 101.2 \\
Kopyor fruit yield/palm/year $^{3)}$ & NA & 34.9 & 23.7 & 29.3 \\
Kopyor fruit percentage $^{4)}$ & NA & 36.6 & 38.2 & 29.6 \\
\hline
\end{tabular}

Note: ${ }^{1)}$ Data source: Local Department of Irrigation, Pati, Central Java.

${ }^{2)} 2009$ and 2010 data were from "Proposal Pelepasan Tiga Varietas Unggul Lokal Kelapa Genjah Kopyor Pati."

${ }^{3)}$ Estimated number based on number of bunches*number of fruit/bunch or number of Kopyor fruit/bunch.

${ }^{4}$ Calculated by using \% Kopyor fruit $=($ Kopyor fruits per inflorescence/fruits per bunch $)$ $* 100 \%$.

NA: data not available. *Data up to August 2010

These activities are currently on going and the results will be presented elsewhere.

\section{Conclusions}

1. The observed yield and yield parameters of three Pati Dwarf Kopyor coconut varieties fluctuated by the year of observation. Generally, the observed yield and yield parameters among three Pati Dwarf Kopyor coconut varieties were similar.

2. The average number of fruit bunches observed among three Pati Dwarf Kopyor Coconut varieties evaluated ranged from 9.6-12.1; the average number of fruits/bunch ranged from 5.3-12.4; and the average number of Kopyor fruits/bunch ranged from 2.0-3.8. The estimated number of total fruits/palm/year among three varieties ranged from 53.8-128.1.

3. The percentage of Kopyor fruit formation observed among three varieties evaluated ranged from 24.8-38.9. While the estimated number of total Kopyor fruits/palm/year ranged from 20.5-39.2, respectively.

4. Rainfall pattern might affect directly or indirectly toward Kopyor fruit yield and yield components of the three Pati Dwarf Kopyor coconut varieties.

\section{Acknowledgment}

This research was partially supported by HI-LINK Kopyor Coconut 2012 Project, Directorate Generale of Higher Education, Ministry of Education and Culture, Republic of Indonesia, entitled: 'Produksi Bibit Kopyor True-To-Type Dengan Persilangan Terkontrol dan Peningkatan Produksi Buah Kopyor Dengan Polinator Lebah Madu," coordinated by Sudarsono. The authors would like to acknowledge the support of "Dinas Kehutanan dan Perkebunan, Kabupaten Pati, Jawa Tengah" and to thank you Mr. Agus Susetyo Purwono for his assistance in field works. 


\section{References}

Asmah N. 1999. Analisis protein spesifik sebagai penanda sifat Kopyor pada kelapa. Skripsi. Jurusan Kimia FMIPA. IPB. Bogor (in Indonesian with English abstract).

Akuba RH, N. Mashud, dan Miftahorracman. 2002. Identifikasi plasmanutfah kelapa potensial di Jawa Timur. Laporan Hasil Penelitian Balitka Manado (in Indonesian with English abstract).

Falconer DS. 1985. Introduction to Quantitative Genetics. Longman Publ. London and New York.

Mahmud Z. 2000. Petunjuk Teknis Budidaya Kelapa Kopyor. Departemen Kehutanan dan Perkebunan. Dirjen Perkebunan. Jakarta (in Indonesian).

Maskromo I. 2005. Kemiripan genetik populasi kelapa berbuah Kopyor berdasarkan karakter morfologi dan penanda DNA SSR (Simple Sequence Repeats) [thesis]. Bogor: Sekolah Pascasarjana. Institut Pertanian Bogor (in Indonesian with English abstract).

Maskromo I dan H. Novarianto. 2007. Potensi genetik kelapa Kopyor Genjah. Warta Penelitian dan Pengembangan Pertanian 29(1):3-5 (in Indonesian with English abstract).

Maskromo I, H. Novarianto dan Sudarsono. 2011. Fenologi pembungaan tiga varietas kelapa Genjah Kopyor Pati. Prosiding Seminar Nasional Perhimpunan Hortikultura Indonesia. Kerjasama PERHORTI, IPB dan Badan Litbang Pertanian, Kementerian Pertanian. Hal. 1001 -1009 (in Indonesian with English abstract).

Maskromo I, H. Novarianto, Dewi Sukma dan Sudarsono. 2012. Potensi hasil plasma nutfah kelapa Kopyor asal Kalianda , Pati, Sumenep dan Jember. Prosiding Seminar Nasional PERIPI Komda Jabar, Program Studi Pemuliaan Tanaman, Fakultas Pertanian Universitas Padjadjaran,
Bandung. Hal 499 - 507 (in Indonesian with English abstract).

Mujer MV, DA. Ramirez and EMT. Mendoza. 1984. Coconut $\alpha$-D-Galactosidase isoenzime: Isolation purification and characterization. Phytochemistry 23:12511254.

Naresh-Kumar, S. 2002. Agro-meteorology and drought management in coconut, In : Training Manual on Drought Stress and Its Management in Plantation Crops. Central Plantation Crops Research Institute, Kasaragod, India.

Perera PIP, V. Hocher, LK. Weerakoon, DMD. Yakandawala, SC. Fernando, and JL. Verdeil. 2010. Early inflorescence and floral development in Cocos nucifera L. (Arecaceae: Arecoideae). South African J. Bot. 76:482-492.

Rajagopal V., S. Shivashankar and J. Mathew. 1996. Impact of dry spells on the the ontogeny of coconut fruits and its relation to yield. Plantation Research and Development 3(4):251-255.

Rajagopal V., KV. Kasturi Bai and S. NareshKumar. 2000. Drought management in plantation crops, pp. 30-35. In: Plantation Crops Research and Development in the New Millennium. Abstracts of PLACROSYM XV, 10-13 December 2002, Mysore, India.

Samonte LJ., EMT. Mendoza, LL. Ilag, ND. De La Cruz and DA. Ramirez. 1989. Galactomannan degrading enzyme in maturing normal and makapuno and germinating normal coconut endosperm. Phytochemistry 28:2269-2273.

Santos GA. 1999. Potential use of clonal propagation in coconut improvement program. In Oropeza C, JL. Verdiel, GR. Ashburner, R. Cardena, JM. Samantha (eds.) Current Advances in Coconut Biotechnology - Current Plant Science and Biotechnology in Agriculture. Kluwer Acad. Publ., London. pp. 419 - 430. 
Santoso U., K. Kuno, T. Ota, T. Tadokoro and A. Maekawa. 1996. Nutrient composition of Kopyor coconut (Cocos nucifera L.). Food Chemistry 57 (2):299-204.

Sayeed P. M. 1955. Some observations on the shedding on buttons in the coconut. Indian Coconut J. 8:49.

Sudarsono, H. Novarianto, Sukendah dan I. Maskromo. 2011. Peningkatan persentase buah Kopyor $(75 \%)$ melalui pemuliaan tanaman dan deteksi dini bibit kelapa Kopyor dengan marka molekuler. Laporan Hasil Penelitian KKP3T. Kerjasama Institut Pertanian Bogor dan Sekretariat Badan Penelitian dan Pengembangan Pertanian (in Indonesian with English abstract).

Sudarsono, Sudradjat, H. Novarianto, M.L.A. Hosang, D. Dinarti. M.S. Rahayu dan I. Maskromo. 2012. Produksi bibit Kopyor true to type dengan persilangan terkontrol dan peningkatan produksi buah Kopyor dengan polinator lebah madu. Laporan Hasil Penelitian Program HI-LINK. Institut Pertanian Bogor (in Indonesian with English abstract).

Sukendah, H. Volkaert and Sudarsono. 2009. Isolation and analysis of DNA fragment of genes related to Kopyor trait in coconut plant. Indonesian Journal of Biotechnology. 14(2):1169-1178. 